\title{
Shifting Theories, Methods and Topics. Monika Salzbrunn Talks with Ludger Pries about Thirty Years of Migration Studies
}

Théories, méthodes et sujets changeants. Monika Salzbrunn discute avec Ludger Pries sur trente ans d'études migratoires

Teorías, métodos y temáticas en mutación. Monika Salzbrunn conversa con Ludger Pries sobre los treinta últimos años de estudios migratorios

\section{Monika Salzbrunn}

\section{OpenEdition}

\section{Journals}

Electronic version

URL: https://journals.openedition.org/remi/8282

DOI: 10.4000/remi.8282

ISSN: $1777-5418$

Publisher

Université de Poitiers

Printed version

Date of publication: 1 December 2016

Number of pages: 231-247

ISBN: 979-10-90426-29-0

ISSN: 0765-0752

Electronic reference

Monika Salzbrunn, "Shifting Theories, Methods and Topics. Monika Salzbrunn Talks with Ludger Pries about Thirty Years of Migration Studies", Revue européenne des migrations internationales [Online], vol. 32 - $n^{\circ} 3$ et 4 | 2016, Online since 01 December 2018, connection on 14 April 2022. URL: http:// journals.openedition.org/remi/8282 ; DOI: https://doi.org/10.4000/remi.8282 


\section{Shifting Theories, Methods and Topics. Monika Salzbrunn Talks with Ludger Pries about Thirty Years of Migration Studies}

\section{Monika Salzbrunn ${ }^{1}$}

\section{Introduction}

The 30th anniversary of the Revue Européenne des Migrations Internationales ( $R E M I)$ cannot be celebrated without reflecting on the shifting theories, methods and topics that have occurred in migration studies over the course of the last thirty years: the link between migration and mobility (Ortar, Salzbrunn and Stock, in press), migration, globalisation and development and, finally, the transnational turn. Ludger Pries' way of structuring the evolution of key concepts in migration studies leads to a better understanding of the contemporary evolution of theoretical thinking. In the present interview, he defines seven ideal types of internationalisation processes: internationalisation, supra-nationalisation, re-nationalisation, deterritorialisation, glocalisation (as a result of the critique of globalisation, a combination of the global as one place and local societal spaces), diaspora building and, lastly, the emergence of a framework of transnational local places that make up coherent societal spaces (transnationalisation). The combination of substantial and relational concepts of space has led to the elaboration of transnational social spaces, emphasising the pluri-local nature of societal relations, networks and practices. These practices include an everyday awareness and interrelation of actors, significant symbols and the use of artefacts. Transnationalisation is defined as a process spanning above and between container spaces and in which the concentric circles of local, micro-regional, national, macro-regional and global phenomena are played out. Ludger Pries has applied this concept to different empirical fields, among them Mexican migrants in the United States of America. Furthermore, he has worked on transnational migrant organisations. In the present interview, he refers to the way the present situation of refugees is treated in light of these different levels of analysis. His latest book (Pries, 2016) deals with migration and arrival, as well as with the possibilities and opportunities of the refugee movement.

1 Professeure de Religions, Migration, Diasporas, ISSRC, Université de Lausanne, Anthropole 5067, 1015 Lausanne, Suisse ; monika.salzbrunn@unil.ch 
Monika Salzbrunn (MS):The Revue Européenne des Migrations Internationales $(R E M I)$ is celebrating its 30th anniversary. What have been the most important shifts in theory, methods and applications of migration studies during the last thirty years according to you?

Ludger Pries (LP): In terms of theory and concepts the most important shift has been to critically revise the methodological nationalism prevailing until the 1980s. Migration could no longer be considered as a simple "container hopping" from one nation state and national society to another. This cognitive frame induced the dominant assimilation approach in classic migration theories. According to that, integration is figured out as a step by step uni-linear adapting of immigrants to the host society. During the last decades the approach to migration as well as integration patterns broadened: migration could be considered as in the classic way, but it also happens as an iterative multi-directional process of transnational migration that goes on during several generations. Accordingly, and supported by new communication and transportation technologies, integration could proceed in the classic sense of assimilation, but it also could occur as segmented, multiple or transnational integration into complex social spaces that could span pluri-locally across countries. In terms of methods there are, on the one hand, substantial innovations in capturing and analysing longitudinal data on life and migration trajectories (like in the Mexican Migration Project at Princeton University). We now are able to combine longitudinal cuts of quantitative research with the qualitative data of life histories and biographical interviews. On the other hand, the methods for multi-sited and multi-level analysis of migration and integration processes improved a lot. By tracing people, goods, stories, symbols, etc. (Marcus, 1995) the intertwined pluri-local social spaces and realities can be analysed.

MS: Can you tell us more about the way you contributed to renew the sociological thinking about spaces, namely the link between a substantial and a relational concept of space?

LP: All human imaginary and thinking contains concepts of the spatial and of spacing. For instance, if we speak about social inequality, we imagine distances between the richest and the poorest social groups. The term "distance" is a spatial reference. If we speak of "mental maps" as important components of personal identities, we refer to complex configurations and frames by which we organise our experiences and world views. Again, the term "maps" is a spatial reference. So, all human perception of the social world - of the "world of everyday life" (Alfred Schütz) as well as its scientific concepts and representations - includes concepts of time and space. Therefore, the concept of space and the spatial not only refers to geography, to physical extensions or to artefacts, but also all our social praxis is embedded in concepts of space in the sense of positions of and relations between socially important elements in terms of distance, distribution, density, front/back stage, hierarchy and centre-periphery. In social sciences, the so-called "spatial turn" reflects the growing awareness of the spatial dimension of the Social in general. In times of globalisation, transnationalisation, glocalisation, etc. it is essential to explicitly include the spatial dimension and the spacing of the Social in all scientific analysis and models. In this context, some scholars like Castells (1997) or Urry (2001) used terms like de-territorialisation or "spaces of flows" in order of characterise spatial aspects 
of tendencies of social change. One could argue that due to the internet, new communication technologies, etc. physical space and geographic territories are of decreasing importance for social life - people could maintain strong ties over long geographic distances. I do not agree with such an approach of vanishing significance of physical spaces and geographic territories because there is a dialectic relation between the Spatial and the Social. Social relations of power and of significance always strike down and are condensed in physical spaces and artefacts (like buildings, real estate properties, boundaries and frontiers). Geographic territories are not of diminishing importance, as it is demonstrated by the wars in Syria and Iraq or by the bloody conflicts between drug cartels all over the world for controlling specific areas. These examples lead me also to a sceptical view on the so called "constructivist turn" if this is put not as an important supplement, but as a new religion. Actually, all physical spaces as well as all social spaces and spatial imaginaries, are socially constructed. This is an important - but not at all new - point. Approaches of functionalism and structuralism normally take "social systems" or structures of meanings as given and are unable to analyse and explain their social and historical making. But it would be like "throwing out the baby with the bath water" if we neglect the crucial role of artefacts, structures and mechanisms - as outcomes and, at the same time, as structuring elements of the social praxis.

This leads to accept that - in spite of dissolving the Spatial in de-territorialisation and "spaces of flows" - we have to explicitly relate the Social and the Spatial, and - in spite of dissipating substantial or absolutist concepts of space in the eternal regress of deconstruction - to combine substantial and relational concepts of space. Based on these considerations, I began to revise scientific concepts of space and found very stimulating a huge volume written by Gosztonyi (1976) where concepts of space are analysed for all scientific disciplines. Gosztonyi identifies more than twenty ideal types of concepts of space, two important and contrasting are a substantial/absolutist and a relational/constructivist view on space. Albert Einstein had criticised with the term "container-space" the traditional concept of space developed by classical Newtonian mechanics. In this "substantial" or "absolutist" view, space has a quality of its own, exists free of concrete objects, but is nevertheless empirically real as a homogeneous and "empty" entity. Not only Einstein, but much earlier Gottfried Leibniz as well, developed a theory opposing this absolutist concept of space. Leibniz felt that space possesses no existential qualities of its own whatsoever, but is rather a configuration of material objects in geographic relations and order. This opposition of absolutist views - space as an absolute unit with its own characteristics and qualities - and relativistic concepts - space as configuration or positional relations between elements - has continued to pervade all scientific concepts of space for centuries (Gregory and Urry, 1985). We induce that during the short time that sociology as a scientific discipline has existed (about one century or so) the absolutist container approach has been dominant. From Durkheim and Simmel up to the main sociological paradigms of today, the leading framework of reference for social space has been the national society which coincided with the geographic space of the nation-state. Absolutist concepts of space are not limited to the concept of the nation state, but can also be found - as shown above - in definitions of civilisations or ethnic and social groups in a static, a-historical and essentialist manner. 
The absolutist definition of space as an entity by itself led to a "container concept" of national societies in nation-states as the most important framework for sociological analysis. One could argue that, for most of this century, this focus may have been sufficient. But now we need new perspectives on the relation between the social and the spatial, respectively, between the social space and the geographic space. Without succumbing to an extremely constructivist position, we have to combine "absolutist approaches" with "relativist approaches" in our studies of space and we have to consider the spatial dimension of the social as a relatively independent analytic category.

The relativist approach focuses on space as a set of relations between the positions of socially important elements that structure human activities and, at the same time, are structured by human activities. The relations between the positions of socially important elements can be defined by referring to distance, spatial distribution, density, front/back stage, hierarchy and centre-periphery. In a relativist perspective, social relations are not framed in a given (container) space, but constitute space: without elements such as social practices, artefacts, and symbols, there is no socially or sociologically relevant space. In this sense, the social space of a neighbourhood does not consist of the social practices and mental mapping of its inhabitants within a given geographically demarcated "container". But the social space of a neighbourhood is conceptualised as a configuration of social practices, systems of symbols and artefacts with spatialpositional relations as a genuine aspect and outcome, but not an independent precondition.

Although the relativist position is absolutely adequate for certain purposes, the absolutist position is also appropriate at times. Human coexistence and social action is not possible without demarcations, boundaries and frontiers that include and exclude. The first distinction of this type that a baby learns is the difference between the subject "self" and surrounding objects. Later on it distinguishes between "ego" and "alter", and between "we" and "them". Therefore, if the material conditions, social practices, beliefs, interests and/or life projects of a certain group of people are the same or highly shared, and differ strongly from those of other groups, then their social space could be considered a container (or a "relative container"). The most basic "container" in this sense is the human body and the individual "ego" (even if we could dilute it - in a relativistic perspective - into just one lump of dense relations between elements located in the broader swinging of all elements of the cosmos). The household or family and the neighbourhood or community as social spaces are "relative absolute containers". Even if we acknowledge that the household or a specific neighbourhood are the socio-spatial outcomes of social relations and processes, they become more or less objective preconditions for the everyday life of the concrete actors. To them they may appear as absolutist containers that delimit and structure their social spaces. In sum, we have to combine substantial and relational concepts of space in order to analyse, explain and understand our current world and the dynamics of social change.

MS: In your books Die Transnationalisierung der sozialen Welt (2008) and Transnationalisierung. Theorie und Empirie grenzüberschreitender Vergesellschaftung (2010), you refer to different ideal-types of internationalisation processes (Pries, 2008: 132-133), to four types of migration (Pries, 2010: 59) 
and to multiple and multi-local incorporation processes of a trans-migrant (Pries, 2010: 64). Could you provide these schemes in English and explain how you developed those and how they can be applied to contemporary phenomena (by giving examples from your empirical research)?

LP: In a more extensive article (Pries, 2005) I developed a proposal of seven different ideal types of internationalisation that are based on the distinction between relational and substantial concepts of space: "The typology [...] takes into account two basic forms of geographic-societal spaces beyond, alongside and above the formerly dominant national society paradigm. One form maintains the double exclusiveness of societal and geographic space found in the absolutist approach. Interconnections between the national containers can be intensified (inter-nationalisation); the geographic-societal scope of the containers themselves can be reduced (re-nationalisation) or widened (supranationalisation and globalisation)". The second form decouples the exclusive relationship between societal and geographic space, allowing for the formation of pluri-local, dense and durable agglomerations of societal practices, symbols and artefacts. This can lead to the evolution of satellites attached to an imagined "motherland" or nation (diaspora building), to the combination of the global as one place and local societal spaces (glocalisation), and to the emergence of a framework of transnational local places building coherent societal spaces (transnationalisation). In the following section, these seven ideal-typical configurations of geographic and societal spaces and their continuing evolution will be sketched out.

The first ideal-typical configuration is "inter-nationalisation". It refers to intergovernmental relations and interactions between sovereign nation-states. Examples of such political and inter-state relations include, for instance, the labour migrant treaties and the accompanying movements between Italy and Germany (1955) or Turkey and Germany (1961); the friendship treaty of 1927 between Italy and Hungary; the foundation of the European Community for Coal and Steel by France, Germany, Italy and the Benelux countries in 1951 or the negotiation and signing of the North American Free Trade Agreement (NAFTA) between Canada, Mexico and the USA. The main characteristic of this configuration is the predominance of nation-state activities and the perception of the inter-national relations as based on national container societies. This ideal type is not limited to the activities of political leaders. On the contrary, it is always based on, reproduces or leads to actions involving the masses (or at least seeming to do so). Economic exchanges between important national trading companies, ideological national movements and mobilisations, boundary spanning relations between national associations of artists or scientists could also form the basis of or emerge from inter-nationalisation. In any case, the point of reference is the interaction between spatially coherent, nationally bounded units of action. This type of increasing significance of inter-national contacts and societal exchange historically developed at the pace of nation-building processes themselves. But its weight in the current socio-geographic processes is obviously not diminishing; the conflict between India and Pakistan is a contemporary example of risky and highly dangerous inter-nationalisation. In the social sciences, internationalisation is analysed primarily by political scientists in the traditional subdiscipline of international relations. 
The second configuration is termed "supra-nationalisation". It stands for the tendency to "upgrade" the logic underlying the nation-state and national container society concepts into supra-national - but not totally global - units. Some aspects of the European Community, such as the European Commission, could be considered as an outcome of supra-nationalisation. In this case, the legitimate sovereign for regulating and representing certain (but until now not the most relevant) issues is not a nation-state but a kind of "supra-nation-state". Supra-nationalisation creates supra-national units which are more than the sum of national units. Supra-national units and actors have their own legal, financial and material basis and develop a new supra-national logic of their own, which goes beyond the logic of inter-national relations between national units. If international organisations (e.g. trade unions or professional associations like the International Sociological Association) are organised on the basis of national delegations, they are inter-national organisations; however, if they are organised (financially, in terms of voting system, etc.) on the basis of individual membership and supranational structures, then they could be considered as supra-national organisations (see the European Sociological Association). Building the NAFTA region could be considered as a step towards economic supra-nationalisation with remaining, but softly "punctured", national polities. The European Union could acquire more and more elements of a supra-national unit, such as the European Court of Justice and the European Court of Auditors. The process of passing an European guideline for the compulsory national development of laws for the construction of European Workers' Councils is an example of a complex mix of supra-nationalisation, maintenance of national sovereignty and transnationalisation.

The third configuration, "re-nationalisation", refers to a certain kind of counter-tendency to the (aforementioned) supra-nationalisation and (yet to be addressed) globalisation processes. Re-nationalisation therefore refers to 1) a strengthening of existing national container boundaries (as one possible outcome of intensified, hostile inter-national interactions); or 2) to the process of dividing formerly more or less homogeneous socio-geographic container spaces into various new societal entities or spaces claiming their own geographic space and territories (regionalisation). In striving for autonomy, the Basques and Bretons are calling for new regional geographic boundaries; the dissolution of the former Soviet Union and the former Yugoslavia led to a multiplicity of nationalisms and regional movements, as well as to the creation of new political entities (or at least competencies) at a level below the national. The European Community's protective Common Agricultural Policy and the USA's unilaterally declared protective steel tariffs are examples of an emerging or ongoing process of "social closure" engaged in by strong nation-states against globalisation and "neo-liberalisation". Nation-states have certainly not relinquished control over flows of goods and services: in many cases these have merely changed the form of control (e.g. the conversion of tariff barriers into non-tariff barriers). The re-emergence or strengthening of national or micro-regional societal spaces, the strengthening of existing territorial boundaries, or the division of formerly more or less homogeneous container spaces into various new contiguous societal container spaces are not old-fashioned relics of the nineteenth and twentieth centuries. Rather, they are an integral part of the dynamics driving the reconfiguration of socio-geographic spaces: indeed, during the last two decades the number of sovereign nation-states involved in the United Nations has grown by approximately one third to almost 200. 
The fourth (and often-cited) configuration is constituted by the dynamics of globalisation. It refers, on the one hand, to the worldwide spanning and extension of international transactions, communications, societal practices, symbols and the impact of these, and to the worldwide perception and awareness of problems, risks, rights, tendencies and incidences, on the other. According to Giddens (1990: 63) "globalisation can thus be defined as the intensification of worldwide social relations which link distant localities in such a way that local happenings are shaped by events occurring many miles away and vice versa". There are a lot of phenomena, such as nuclear risks and global warming, that have specific local, micro-regional, national, macro-regional or inter-national origins, but whose consequences are felt by each country and individual around the globe. Obviously people and countries with a lot of economic knowledge and other resources will better be able to respond to such global challenges, but they will be affected by them, one way or another. Therefore, globalisation refers (at least partially and in the long run) to worldwide and omnipresent societal affairs, interactions, communications, societal practices, symbols, events risks and rights. Regarding its corresponding relations between geographic and societal space, globalisation often is conceptualised either as the geographic widening of societal relations and spaces (as indicated in the Giddens' quotation above) or as the annihilation of space and the "compression of our spatial and temporal worlds" (Harvey, 1989; see also Waters, 1995: 3).

The configurations addressed so far have in common that the double exclusiveness of geographic and societal space is not questioned or uncoupled substantially; rather, it is geographically reduced or widened. Even in the globalisation approach the relation between geographic and societal space is thought of as being coherent and contiguous. As Brenner (1999) has argued, globalisation research often takes either a "global territorialist" or a "deterritorialisation" approach. The former represents global space in a state-centric manner, "as a pregiven territorial container within which globalisation unfolds" (Brenner, 1999: 59). The other alternative, which he denotes as the "deterritorialisation" approach, envisions the spatial dimension as losing its significance altogether. For theorists in this vein, the transition from geographic space (i.e. physical place) to "cyberspace", and the resultant loss of significance of the spatial dimension, causes everything to dissolve into a borderless "space of flows" (Urry, 2001). In contrast to these approaches, both of which presuppose one contiguous geographic space, the following three ideal-types are based on the relativist concept of one societal space which spans several geographic places. Whereas in the aforementioned configurations relations between sociogeographic containers are intensified and their reach widened or reduced, the following configurations involve contiguous and coherent, dense and durable societal spaces in multi-layered geographic spaces.

The fifth configuration is a product of critics of the globalisation concept. Whereas globalisation discourse often emphasised the disappearance or annihilation of geographic space, the "de-territorialisation" of the societal, or the "recession of the constraints of geography" (Waters, 1995), the term glocalisation (Robertson, 1994) focuses on the dialectics between globalisation and localisation. Global tendencies and processes are related to and interconnected with local concentrations of power, technology, knowledge, money and other resources and occurrences. Also, the tendency to sweep away some borders 
often goes hand in hand with the drawing of new borders. To perceive globalisation as a process aimed solely at gradually reducing the significance of geographic space and boundaries is to ignore the mounting efforts to establish new mechanisms of inclusion and exclusion at various territorial levels, or to deny the locally tangible effects of globalisation processes. For instance, global warming not only has dramatic local effects, it has its origins in locally bounded causes (such as the energy consumption patterns of some OECD countries). The same is true for the global diffusion of fashions and nutrition habits, for the corresponding decline of isolated local economies, and for the increase in so-called "diseases of civilisation". Similarly, the expansion of locally concentrated software economies, like the one in Bangalore, India, is the result of a more or less globalised market for special software services (and the very fact that it is located in a time zone that is just half a day removed from the USA). In sum, glocalisation strengthens or produces pluri-local societal spaces in which globalised/delocalised phenomena and processes collide with the localised concentration of preconditions and/or effects of such phenomena and processes. Glocalisation involves two geographic levels as sites of interaction: the "global" and the "local".

The sixth ideal-typical configuration is diaspora-building, which conceives of diasporas as multi-sited, dense and durable societal spaces with an identifiable (even if only imagined) centre. Though the term is used in many different ways, the common idea we will stress here is the existence of a shared societal space which spreads over different geographic spaces and boundaries of regions or nations, and which is constituted mainly in reference to a common "motherland" or clearly identifiable centre. The most important historical type of a diasporic societal space is the Jewish experience of dispersion and persecution over many places and nations, in which references to and images of a common homeland provided the nexus (Cohen, 1997). In a more general sense, the dense and durable societal spaces created by diplomatic corps or politically persecuted refugees with their "homelands" could also be considered as diasporas, insofar as people in the "peripheries" (embassies, settlements etc.) are driven by religious or political reasons to maintain strong loyalty to the sending centre. In the case of Indian migration towards Australia, Voigt-Graf (2004) differentiated between diaspora communities with traditional cultural hearths and those with new centres.

Vertovec distinguishes three different meanings of the term diaspora (as a social form, as a type of consciousness and as a mode of cultural production), and he defines a diaspora as "practically any population which is considered 'deterritorialised' or 'transnational' - that is, whose cultural origins are said to have arisen in a land other than that in which they currently reside, and whose social, economic and political networks cross borders of nation-states or, indeed, span the globe" (Vertovec, 2000: 141). For our understanding, this is a very broad concept of diaspora. As we discussed above, the notion that the societal becomes "de-territorialised" is highly questionable. Of course it is important to distinguish different notions of diasporas according to the quality of societal spaces they embody. However, our purpose here is to distinguish among idealtypical configurations of societal and geographic spaces. 
This leads us to the seventh and final configuration: transnationalisation. This denotes a growing phenomenon in terms of its quantitative and qualitative significance, one which emphasises the pluri-local nature of societal relations, networks and practices. Transnationalisation refers to the strengthening or emergence of pluri-local societal configurations which span above and between the traditional container spaces, and in which the concentric circles of local, micro-regional, national, macro-regional and global phenomena are played out. This phenomenon presupposes a relativist concept of societal-geographic space, rather than an absolutist one. Thus, transnational societal spaces can be understood as pluri-local frames of reference which structure everyday practices, social positions, biographical employment projects, and human identities, and which span above, between and beyond the contexts of national container societies.

Transnationalisation as a process consists of relations and interactions that in some cases strengthen for a while and then dilute again, but it also could lead to the emergence of relatively stable and durable transnational societal spaces. According to their level of institutionalisation, fixedness or strength, and according to general sociological understanding, three types of such societal spaces could be distinguished: 1) habitual and accountable patterns of action and behaviour in transnational everyday life; 2 ) transnational organisations as stable and dense loci of cooperation and interaction with rules of membership, given structures and processes, and stated goals and purposes; or 3) transnational institutions as complex frameworks of routines, rules and norms, which structure significant terrains of life.

Transnational societal spaces have been analysed in a wide range of contexts spanning from migration networks (see Portes et al., 1999 for an overview), migration organisations (Østergaard-Nielsen, 2001), business organisations (Bartlett and Ghoshal, 1989; see also Carroll and Fennema, 2002; Hirsch-Kreinsen, 1997) and informal, criminal and terrorist activities (Passas, 2003), to networks of Muslim intellectuals in the eighteenth century (Reichmuth, 2000). Smith (2001: 5) underlined the place-making aspects of transnational spaces in their geographic and societal dimension in defining transnationalism as "a marker of the crisscrossing transnational circuits of communication and cross-cutting local, translocal, and transnational social practices that 'come together' in particular places at particular times and enter into the contested politics of place-making, the social construction of power differentials, and the making of individual, group, national, and transnational identities, and their corresponding fields of difference". Referring to the work of Michael Kearney, Smith (2001: 3) argues "while the globalisation discourse draws attention to social processes that are 'largely decentred from specific national territories', as in the case of Manuel Castell's (1997) discussion of globalisation(s) as taking place in a 'space of flows', research on transnational processes depicts transnational social relations as 'anchored in' while also transcending one or more nation-states" (Pries, 2005: 171-174).

Concerning the term "transmigrant", the corresponding concept was first coined by US-American migration scholars in the context of the transnationalism approach. I proposed to differentiate four ideal-types of international migrants by their specific relation to their "region of departure" and their "region of arrival" (these terms are sticky, because in the case of sequential, 
recurrent, circular, pendular or chain migration there is neither a clear region of departure nor of arrival), by the motivation for moving and by the time horizon of their migration decisions: emigrant/immigrant, return-migrant, Diasporamigrant and transmigrant.

An example that comes near to the ideal-type of emigrant/immigrant is millions of Europeans who left their countries at the turning from the 19th to the 20th century towards the USA. In search for better economic and sociocultural conditions they integrated to the USA as their new homeland in a long term and unlimited perspective; they maintained manifold ties to their regions of origin as the social and geographic space of their roots and ancestry - being aware that these ties were increasingly linkages of historical reminiscence and everyday farewell. In contrast, an ideal-typical return-migrant was the European "guestworker" of the 1960s and 1970s; his time horizon was short term, limited to a period of some years in which he tried to earn sufficient money, e.g. for putting his own business in the region of his origin; therefore, for him the region of arrival was just a "host country" to which he maintained social differences.

The ideal-type of a Diaspora-migrant could be exemplified by Jewish people and communities distributed all over the world; often driven by religious, political or reasons of a dominating organisation (such as a diplomatic corps or a business organisation), Diaspora-migrants maintain strong symbolic ties to their region of origin as the "motherland", and experience the region of arrival as a space of suffering or of mission. The transmigrants typically do not distinguish by this way between region of origin and of arrival, but develop an ambiguous mixture of inclusion and maintaining differences as well; transmigrants move frequently between countries, and their decisions are taken not in a short or long term, but in a sequential manner.

MS: You mention that migration has often been researched in relation to integration patterns, which have evolved during the last decade. Would you say that migrants are considered as agents or "scale-makers" (as Nina Glick Schiller and Ayse Caglar define them in their book on Locating Migration. Rescaling Cities and Migrants) from now on?

LP: In social sciences, migration has actually been considered mainly as a "container hopping" from one place of sedentary life to another, being it from one city to another (internal migration) or from one country to another (international migration). In fact, much of migration processes during the last centuries could be characterised this way. But looking in a broader way at migration in history of mankind, there always existed different types of geographic mobility: recurrent mobility from one place to another (traders, merchants, business people, diplomats) with several centres of ones living world, return migration as leaving one place in order to do something in another place (work, diplomacy, religion) and coming back to the - unilocal - centre of ones living world, unidirectional and nonrecurring migration from one place to another changing the unilocal centre of ones living world. In this respect, migrants always have been "scale-makers" in the sense of structuring and constructing parts of the social worlds of societal living in general. Since the last quarter of the 20th century, with economic globalisation, new global communication technologies facilitated by the internet, cultural productions and movements at different spatial levels 
there are complex processes of "rescaling" or scale restructuring in the sense of what I call the restructuring of the relation between social and geographic spaces. Migrants and migration are part of that, but the rescaling of social spaces has a much broader scope including almost all aspects of social, cultural, political and economic life and many different qualities reaching from (re-)localising, (re-)nationalising over transnationalising up to globalising.

MS: Some researchers argue that despite the critique on "methodological nationalism", migrants are still analysed in an essentialising way, e.g. when we follow networks based on a common citizenship. Do you agree with this (self-) critique?

LP: I would agree with this critique if it is related to those who study migrants exclusively or predominantly based on their citizenship. But, first, criticising methodological nationalism for me does not mean to deny the central role of nation states and national societies in the current world. The number of nation states registered at the United Nations increased by a third during the last half century. Where states "fail" or where we speak of "failed states" things get worse for most people living there. So critique of methodological nationalism should not "throw out the baby with the bathwater". This leads to recognise the crucial role e.g. of citizenship as a key to different kinds of rights and duties. Second, when analysing local, regional or cross-border migration, the research lens should not and normally is not limited to citizenship aspects but includes a broad variety of important factors like gender, education, economic resources, political power relations and de facto citizenship are structuring migration (networks) as well and sometimes in a more significant way than formal citizenship.

MS: In a paper about "Muslims going public - Building local citizenship through speech, food and music" presented at the 2016 EASA (European Association of Social Anthropologists) panel on "Complicating contemporary understandings of citizenship and belonging", we actually suggest that the formal understanding of citizenship is not sufficient since immaterial and symbolic aspects play an important role, namely in a context of struggle for recognition. This way of thinking citizenship and belonging are close to your definition of social practices, symbols and artefacts as dimensions of social spaces (2010: 157). Could you give us more details about the way you structure the types, dimensions and levels of social spaces?

LP: Formal citizenship always is an outcome of specific mechanisms to reproduce differences, belongings and social spaces. Diversity always means socially constructed differences in relational frameworks of unequal distribution of social status. Diversity goes hand in hand with power relations, interests and fights for resources and recognition. Once distinctions are made and diversities are constructed, some of these distinctions institutionalise in specific social spaces - or, looked at the other way round, social spaces institutionalise by substantialising certain patterns of socially invented and constructed distinctions by their members. Citizenship is perhaps the most common substantialised category of belonging. The socially dominant layers of diversity (citizen status, social class, race, ethnicity, religion, culture, language, generation, gender, lifestyle, etc.) change in time as well as in social and geographic space. 
Once nation-states are considered not as naturally given and not as takenfor-granted units of reference but as socially constructed complex frameworks of territorial containers of collective belonging, sovereignty, and rights, their dominant categories of inclusion and exclusion can be analysed as historically created and institutionalised - and therefore also as changeable. What in a certain moment was a relational set of negotiated or imposed mutual demarcations by institutionalisation gets locked into the iron cage as collective imagination of substantial distinctions. When such substantial distinctions are questioned, differentiated or aggregated by new distinctions or additional items in existing categories, the whole framework of belonging starts to wobble.

These dynamics suggest that nation-states with national societies are only one type of social spaces. Social spaces or socio-spaces can be considered as human-life relations with three different dimensions, analogous to the $x, y$ and $z$ axes of social life. First, social practice is the everyday awareness and interrelation of actors with other actors, with nature and with oneself. All three relations (human-nature, human-human and ego-self) are constitutive and indispensable for any form of human life-practice. By definition, these relations imply an expansion in space and time and refer to the active and intervening side of human life entanglements. Work (in the form of hunting, constructing dwellings, sowing and reaping grain, baking bread, building machines, preparing food, etc.) has been the most important social practice in the human-nature relation for millions of years, but it also always encompassed human-human and the ego-self relations.

Significant symbols (like language or norms) constitute the second component of social spaces. As complex and interrelated signs for and within a certain context, symbols are used to frame certain situations with their meanings, while at the same time being subject to constant (re-)construction and negotiation. Symbols are not simply to be understood as sensory inputs, just as, for example, certain light-waves are registered on the retina as signs for the colour red or green, or as the temperature of a fluid or object is registered by the skin as a sign of warmth or cold. Rather, a symbol is a complex sign for and in a context. It represents a mode of giving sense to social practice and of structuring social practice by meaningful behaviour. A symbol is primarily conditioned not by a "natural situation" but rather by culture. Significant symbols evoke the same connotation in differing agents living within the same cultural context. For example, in North-Western European social spaces, a wedding ring represents a very complex context of an enduring (and up until the 20th century heterosexual) relationship based upon mutual affection and free will, approved by religious institutions and by the state. The relative importance of certain systems of symbols (e.g. characters, movies, funeral rituals) can vary tremendously. Language is a very complex, universal and indeed constitutive symbol system in human social spaces.

Thirdly, social spaces always include the existence and use of artefacts, understood as objectified results of human appropriation and action. The idealtypical character of this threefold differentiation can be easily pointed out by referring to the example of the red card in a soccer game, which has to physically exist in the first place (artefact), be pulled by the referee (social practice), and be understood according to its specific punitive connotation (symbol). So artefacts 
include all objectified results stemming from human action, especially human work. As objects formed by humans, artefacts are also always the result of the active human-nature relation. However, the two other human relations - the human-human and the ego-self relation - cannot be separated. Crafting a spear for hunting, forging a ring and preparing a meal are results of and aimed at all three human life relations. Certain social theories are almost blind regarding the importance of artefacts for human beings' social spaces. For example, in Luhmann's system theory (2013) artefacts are not ascribed the deserved systematic consideration when compared with social practices and systems of symbols. It should therefore be stressed that the two other dimensions of social spaces social practices and symbol systems - cannot be understood without making systematic reference to artefacts.

In distinguishing social practices, symbols and artefacts as the three constitutive dimensions of dense and durable social spaces, at least three ideal-types of such social spaces could be identified as relevant for transnational studies: everyday life, organisations and institutions. Some examples of such social spaces are given, and these could extend or contract at different spatial levels. For instance, communicating by phone in a certain language is an everyday activity of millions of people all over the world. It combines a shared social practice (if other people were not used to communicate this way, it would not be such a taken-for-granted part of our life as it is), certain constellation of artefacts (technology of analogue data transfer or using "voice-over IP" by internet, phone, or tablet) and the most significant system of symbols for human beings, language. Obviously, communicating by phone could have a local, microregional, national or macro-regional spatial reach. When using teleconferencing and integrating many persons who are spread over many places in different regions or continents, such communication could have a transnational spatial reach.

When developing his concept of everyday life, Schütz differentiated between two ideal types of the social: the social environment (soziale Umwelt) and the social co-world (soziale Mitwelt) of human beings. According to Schütz, social environment denotes the immediately perceived world as a simultaneity of space, time and the co-presence of a "you"-perspective (in the sense of the awareness other actors involved). It is a world in which "I focus upon the conscious experiences of others by my own vivid and open awareness" (Schütz, 1993: 202). The social environment is therefore oriented towards the alter ego, towards my fellow humans. Schütz distinguishes between the social environment and the social co-world as follows: "Beyond this social environment which connects me to the community in time and space, further social spheres exist. Some, I currently experience because they were formerly my environment and I can (at least in principle) always make them my environment. Others which were never part of my environment and of which I could therefore have no experience, represent possible experiences. Let us call these social regions the social co-world" (ibid.: 202).

Schütz constantly stresses the importance of the simultaneity of space and time for the social environment: "The spatial and temporal immediacy is fundamental for the environmental situation" (ibid.: 228). In my opinion, this is where, at the beginning of the 21 st century, fundamentally new developments arise. 
Modern transport and communication infrastructures available to broad population groups today make conscious experiences of others by my own "vivid and open awareness" possible even across long geo-spatial distances. Thus, social environments can span across several spaces pluri-locally and transnationally more easily than, for example, a century ago. The term "more easily" is meant to imply that pluri-local and boundary-transgressing social spaces have already existed to a certain extent - as in the form of the millennia-old Catholic Church and the even older Jewish Diaspora.

Apart from everyday life on a micro-level, organisations represent a second ideal type of social spaces. They may be defined as relatively durable interactionframeworks (of people) with membership rules (who belongs and who does not belong to the organisation), deliberately established structures and processes of division of labour (who has to do what), rules and rituals of behaviour (what is accepted and expected behaviour and what is not), power (who says what is to be done and who reports to whom) and planned and variable goals and ends. While organisations as ideal typical social spaces are situated on a meso-level, social institutions represent the macro-level of social spaces. They can be understood as inherited frameworks of routines, rules, norms and mutual expectations, which structure specific areas of human life and offer action programmes, identities, integration and stability for relatively expansive interaction-networks (e.g. societies, communities, ethnicities, organisations etc. Examples: heterosexual matrimony, professions, 15th birthday festivity). Whereas persons can belong to organisations and leave them, social institutions cannot be "entered" by persons, but influence them to a certain degree.

MS: According to you, what are the current "hot topics" in migration studies?

LP: For decades the relation between migration and development was analysed extensively. Currently, organised violence and armed conflicts in the Arab region or Africa underline the necessity to relate migration and development (as overcoming extreme poverty, lack of education opportunities, extreme social inequality) to organised violence. All three elements - migration, development, organised violence - represent a crucial triangle of social challenge and influence each other. A second thematic issue refers to transnational citizenship, rights and duties in the context of increasingly dynamic migration processes. Concerning methods and data there is a lack of longitudinal data sources for cross-border migration. Methodological nationalism is reflected in the very fact that organised and continuous data gathering concerning migration dynamics normally is structured by the nation states, whereas the actual processes span their limits.

MS: Multi-sited and multi-level analysis of migration have indeed contributed to fine analysis of intertwined pluri-local social spaces. Can you give an example for this (e.g. based on your own research)? Which are the most important challenges concerning empirical research on migration?

LP: Refugee migration is a central topic in current research. Those who flee from persecution in one site (e.g. Aleppo in Syria) always have multi-sited points of reference of where to go. Family ties at the micro-level provide and connect them with information about the situation in different potential sites 
of arrival (e.g. France, Italy, Germany, and Austria). At the meso-level different types of multi-sited organisations and networks - from refugee related NGOs, semi-public organisations like UNHCR or Red Cross, Frontex and national border control agencies up to criminal networks of smugglers and human traffickers' represent opportunity structures and limitations for refugee migration. Finally, at the meso-level of the European Union and its member states there are important institutionalised structures and processes for dealing with refugees and asylum seekers (like the Common European Asylum System). In order to understand refugee migration dynamics the multiple sites involved as well as the individual, collective and corporate actors have to be analysed at micro, meso and macro levels.

\section{References}

Bartlett Christopher A. and Ghoshal Sumantra (1989) Managing Across Borders. The Transnational Solution, Boston, Harvard Business School Press, 416 p.

Brenner Neil (1999) Beyond state-centrism? Space, territoriality, and geographical scale in globalization studies, Theory and Society, 28 (1), pp. 39-78.

Carroll William K. and Fennema Meindert (2002) Is there a transnational business community?, International Sociology, 17 (3), pp. 393-419.

Castells Manuel (1997) The Power of Identity, Oxford, Blackwell, 582 p.

Cohen Robin (1997) Theories of Migration, Cheltenham/Brookfield, Deward Elgar, 512 p.

Giddens Anthony (1990) The Consequences of Modernity, Stanford, Stanford University Press, $188 \mathrm{p}$.

Glick Schiller Nina and Caglar Ayse (Eds.) (2010) Locating Migration. Rescaling Cities and Migrants, Ithaca, Cornell University Press, 296 p.

Gosztonyi Alexander (1976) Der Raum. Geschichte seiner Probleme in Philosophie und Wissenschaft, Freiburg/München, Alber, $1418 \mathrm{p}$.

Gregory David and Urry John (1985) Introduction, in David Gregory and John Urry Eds., Social relations and spatial structures, Basingstoke/London, MacMillan, pp. 1-8.

Harvey David (1989) The Conditions of Postmodernity, Oxford, Basil Blackwell, $392 \mathrm{p}$.

Hirsch-Kreinsen Hartmut (Ed.) (1997) Organisation und Mitarbeiter im TQM, Berlin, Springer, $312 \mathrm{p}$.

Luhmann Niklas (2013 [2002]) Introduction to Systems Theory [translated by Peter Gilgen], Cambridge, Polity Press, 300 p.

Marcus George H. (1995) Ethnography in/of the World System:The Emergence of Multi-Sited Ethnography, Annual Review of Anthropology, 24, pp. 95-117.

Ortar Nathalie, Salzbrunn Monika et Stock Mathis (Éds.) (à paraître) Migrations, circulations, mobilités. Nouveaux enjeux épistémologiques et conceptuels à l'épreuve du terrain, Paris, Presses de la Sorbonne. 
Østergaard-Nielsen Eva K. (2001) Transnational Political Practices and the Receiving State: Turks and Kurds in Germany and the Netherlands, Global Networks: A Journal of Transnational Affairs, 1 (3), pp. 181-193.

Passas Nikos (2003) Informal Value Transfer Systems, Money Laundering and terrorism, IVTS. A report to the National Institute of Justice, Northeastern University, $137 \mathrm{p}$.

Portes Alejandro, Guarnizo Luis E. and Landolt Patricia (1999) The study of transnationalism: Pitfalls and promise of an emergent research field, Ethnic and Racial Studies, 22, pp. 217-237.

Pries Ludger (2016) Migration and Ankommen. Die Chancen der Flüchtlingsbewegung, Frankfurt am Main, Campus, 208 p.

Pries Ludger (2010) Transnationalisierung. Theorie und Empirie grenzüberschreitender Vergesellschaftung, Berlin, Springer, 192 p.

Pries Ludger (2008) Die Transnationalisierung der sozialen Welt, Frankfurt am Main, Suhrkamp Verlag, 400 p.

Pries Ludger (2005) Configurations of Geographic and Societal Spaces: A sociological proposal between "methodological nationalism" and the "spaces of flows", Global Networks, 5 (2), pp. 167-190.

Reichmuth Stefan (2000) "Netzwerk" und "Weltsystem", Konzepte zur neuzeitlichen "Islamischen Welt" und ihrer Transformation, in Roman Loimeier Ed., Die islamische Welt als Netzwerk: Möglichkeiten und Grenzen des Netzwerkansatzes im islamischen Kontext, Würzbur, Ergon-Verl., pp. 53-86.

Robertson Roland (1994) Globalization or glocalization, Journal of International Communication, 1, pp. 33-52.

Salzbrunn Monika, Bachir-Loopuyt Talia and Dellwo Barbara (2016) Muslims going public. Building local citizenship through speech, food and music. Paper presented at the panel "Complicating contemporary understandings of citizenship and belonging", organised by Beth Rubin and Ellen Skilton, Anthropological legacies and human futures, Milano-Bicocca, [online]. URL: http://nomadit.co.uk/ easa/easa2016/panels.php5?PanelID=4659

Schütz Alfred (1993) Der sinnhafte Aufbau der sozialen Welt. Eine Einleitung in die verstehende Soziologie (6th ed.), Frankfurt, Suhrkamp, 500 p.

Smith Michael P. (2001) Transnational Urbanism: Locating Globalization, Malden, Blackwell, 236 p.

Urry John (2001) Sociology beyond Societies: Mobilities for the Twenty-First Century, London, Routledge, 268 p.

Vertovec Steven (2000) The Hindu Diaspora: Comparative Patterns, London, Routledge, $190 \mathrm{p}$.

Voigt-Graf Carmen (2004) Towards a geography of transnational spaces: Indian transnational communities in Australia, Global Networks, 4 (1), pp. 25-49.

Waters Malcolm (1995) Globalization, London, Routledge, 268 p. 


\section{Monika Salzbrunn}

\section{Shifting Theories, Methods and Topics. Monika Salzbrunn Talks with Ludger Pries about Thirty Years of Migration Studies}

Monika Salzbrunn talks with Ludger Pries about shifting theories, methods and topics that occurred during the last thirty years in migration studies, namely the transnational turn. The combination of substantial and relational concepts of space has led to the elaboration of transnational social spaces, emphasising the pluri-local nature of societal relations, networks and practices. These practices include an everyday awareness and interrelation of actors, significant symbols and the use of artefacts. Transnationalisation is considered as one out of seven ideal-types of internationalisation and migration processes, spanning above and between container spaces and in which the concentric circles of local, micro-regional, national, macro-regional and global phenomena are played out. Finally, the present situation of refugees is treated under the light of these different levels of analysis.

\section{Théories, méthodes et sujets changeants. Monika Salzbrunn discute avec Ludger Pries sur trente ans d'études migratoires}

Monika Salzbrunn s'entretient avec Ludger Pries à propos des changements théoriques, méthodologiques et thématiques - notamment le " tournant transnational " - intervenus durant trente années de recherche sur les migrations. La combinaison des concepts d'espace substantiel et d'espace relationnel a conduit à l'élaboration d'espaces sociaux transnationaux qui souligne le caractère pluri-local des relations sociétales, des réseaux et des pratiques. Ces pratiques comportent une conscience quotidienne et une interrelation d'acteurs, de symboles significatifs et le recours aux artefacts. La transnationalisation est considérée comme un des sept idéaltypes (ideal-types) de processus d'internationalisation et de migration, s'étendant au-dessus et entre des espaces "contenants ", et au sein de laquelle des cercles concentriques de phénomènes locaux, micro-régionaux, nationaux, macro-régionaux et globaux s'articulent. Enfin, la situation actuelle des réfugiés est abordée en tenant compte de ces différents niveaux d'analyse.

\section{Teorías, métodos y temáticas en mutación. Monika Salzbrunn conversa con Ludger Pries sobre los treinta últimos años de estudios migratorios}

Monika Salzbrunn conversa con Ludger Pries sobre los cambios teóricos, metodológicos y temáticos que han ido experimentando en los últimos treinta años, en concreto durante el "cambio transnacional", los estudios sobre las migraciones en ciencias sociales. La combinación de los conceptos de espacio sustancial y espacio relacional del espacio ha llevado a la elaboración de los llamados espacios sociales transnacionales, destacando así el carácter plurilocal de las relaciones sociales, las redes y las prácticas. Esas prácticas implican una consciencia cotidiana y una interrelación de actores, de símbolos significativos y el empleo de "artefactos". La transnacionalización es una de los siete tipos ideales (ideal-types) del proceso de internacionalización y de migración, extendiéndose por encima y entre los espacios "container». En el seno de dicha transnacionalización se articulan círculos concéntricos de fenómenos locales, micro-regionales, nacionales, macro-regionales y globales. Por último, teniendo en cuenta los diferentes niveles de análisis citados, la entrevista aborda la situación actual de los refugiados. 